\title{
BIMBINGAN BELAJAR DI ERA NEW NORMAL MENURUT AJARAN ISLAM
}

\author{
Mat Jalil \\ Institut Agama Islam Negeri (IAIN) Metro \\ buangjalil@gmail.com \\ Agam Anantama \\ Institut Agama Islam Negeri (IAIN) Metro \\ Che_ghumz@ymail.com
}

\begin{abstract}
The quranic tutoring is intended for the formation of intelligent, pious and noble students. To achieve this goal, tutoring is not only aimed at developing and maximizing brain function. But it needs to be balanced with developing and maximizing the function of the heart. This implies that there is a balance between dhikr and indigent activities (QS. 3: 190-191). Tutoring is not only given to students who have diffficulties or problems in their learning, but aimed at all students. Learning and guiding activities are worship activities to Allah. For this reason, both students and mentors need to straighten their intentions before carrying out their activities to hope for the pleasure of Allah SWT.
\end{abstract}

Keyword : Tutoring; New Normal; Islamic Teachings. 


\section{A. Pendahuluan}

Era globalisasi saat ini, yang ditandai dengan pesatnya kemajuan ilmu pengetahuan dan tekhnologi telah membawa manusia kedalam perubahan besar di berbagai kehidupannya baik di sektor ekonomi, politik, sosial, budaya dan pendidikan. Di sektor pendidikan, kemajuan teknologi informasi memegang kunci penting yang menawarkan berbagai kemudahan dalam komunikasi dan interaksi sosial manusia dimanapun belahan bumi berada.

Kemajuan tekhnologi dalam pendidikan semakin terasa manfaatnya oleh umat manusia ketika dilanda pandemi Corona Virus Disease, sebuah wabah penyakit yang dikenal juga dengan nama Covid 19 yang membuat banyak negara menetapkan status darurat nasional untuk melawan virus ini.

Di Indonesia, pemerintah mencegah dan meminimalkan penyebaran pandemi Covid 19 dengan melakukan upaya preventif. Salah satu kebijakan yang diambil pemerintah Indonesia dalam bidang pendidikan adalah melakukan pembelajaran online, yaitu bentuk akifitas belajar-mengajar yang dilkukan dari rumah masing - masing dengan memanfatkan jaringan internet atau biasa dikenal Dalam Jaringan (Daring) ${ }^{1}$.

Perkembangan penyebaran virus corona di Indonesia yang sangat pesat memunculkan kecemasan dalam diri masyarakat. Kecemasan merupakan suatu keadaan khawatir yang merasakan bahwa sesuatu yang buruk akan segera terjadi. Berbagai faktor yang menyebabkan kecemasan muncul antara lain seputar ujian, karier, kondisi lingkungan dan lainnya. Hakikatnya kecemasan, ketakutan ataupun kepanikan jika dipahami dalam ajaran Islam merupakan sepenggal cobaan yang Allah berikan kepada hambaNya, sebagaimana Firman Allah dalam QS. Al-Baqarah ayat 155 sebagai berikut :

"Dan sungguh akan Kami berikan cobaan kepadamu, dengan sedikit ketakutan, kelaparan, kekurangan harta, jiwa dan buah-buahan. Dan berikanlah berita gembira kepada orang-orang yang sabar." (QS. Al-Baqarah : 155) ${ }^{2}$

${ }^{1}$ Bimbingan Belajar "Antara Metode Belajar Di Kelas Sampai Online " (Jakarta: Tempo Publishing, 2019).

2 “Qur'an Kemenag," diakses 9 September 2019, https:/ / quran.kemenag.go.id/. 
Ayat tersebut dapat diketahui bahwa tingkat kecemasan setiap indivdu berbeda antara satu dengan lainnya. Ketakutan dalam menghadapai ujian merupakan suatu cara yang mengarahkan kepada kegagalan. Hal ini disayangkan karena kepanikan masyarakat terhadap penyebaran virus corona cenderung terjadi secara berlebihan. Sedangkan kepanikan berlebihan akan mendahului ketenangan dan keputusan yang dibuat. Kepanikan berlebih mengakibatkan orang bertindak tidak rasional dan mengesampingkan nilai kemanusiaan. Kepanikan semacam ini terjadi tidak hanya secara personal tapi dapat menjelma menjadi kepanikan kelompok atau massa ${ }^{3}$.

Kepanikan sosial seharusnya dinetralisir agar masyarakat tetap bersama-sama waspada dengan cara yang lebih elegan dan manusiawi. Hal ini seperti yang diucapakan oleh salah satu tokoh pemikiran Islam yang terkenal yaitu Ibnu Sina yang berkata "kepanikan adalah separuh penyakit, ketenangan adalah separuh obat dan kesabaran adalah langkah awal kesembuhan".

Kepanikan yang berlebihan dalam menghadapi Covid-19 akan berdampak buruk pada kesehatan diri. Hasil penelitian menunjukan bahwa 95\% penyakit yang diderita berasal dari pikiran yang negatif. Emosi negatif tersebut salah satunya adalah kepanikan berlebihan. ${ }^{4}$

\section{B. Pembahasan}

Pendidikan merupakan aspek terpenting dalam membentuk karakter generasi bangsa. Oleh karena itu, dalam proses pendidikan sangat dihrapkan bagi seorang pendidik agar lebih mampu memfasilitasi pendidikan secara maksimal. Salah satunya adalah dengan menguasai berbagai media pembelajaran terlebih dalam situasi pandemi Covid 19 saat ini. Pandemi yang mewabah seluruh dunia saat ini menuntut umat manusia untuk menyesuaikan dengan keadaan atau disebut dengan istilah New

3 Lis Binti Muawanah, "KEMATANGAN EMOSI, KONSEP DIRI DAN KENAKALAN REMAJA," Persona:Jurnal Psikologi Indonesia 1, no. 1 (1 Juni 2012), https:/ / doi.org/10.30996/persona.v1i1.9.

4 Raka Yusuf, Harni Kusniyati, dan Yurike Nuramelia, "APLIKASI DIAGNOSIS GANGGUAN KECEMASAN MENGGUNAKAN METODE FORWARD CHAINING BERBASIS WEB DENGAN PHP DAN," Jurnal Sistem Informasi, 2016, 13. 
Normal. Dengan menguasai media pembelajaran secara maksimal maka pendidik dapat memberikan bimbingan belajar secara maksimal. Strategi bimbingan adalah salah satu penunjang dalam sebua proses pembelajaran. Berhasil atau tidaknya proses pembelajaran sangat bergantung pada strategi pembelajaran yang digunakan. Strategi bimbingan juga merupakan sesuatu yang dapat digunakan untuk menyalurkan pesan dari pengirim ke penerima sehingga dapat merangsang pikiran, perasaan dan minat peserta didik sedemikian rupa sehingga terjadi proses belajar ${ }^{5}$.

\section{Hakikat Pendidikan}

Pendidikan sejatinya adalah salah satu alternatif dalam mempersiapkan sumber daya manusia untuk menjaga serta dapat memajukan kehidupan. Sejak manusia diciptakan hingga saat ini dan bahkan di masa mendatang memegang peranan penting dalam perkembangan peradaban manusia. Ulama hingga ilmuan tidak akan mampu menjadi seorang yang sukses di bidangnya tanpa melalui proses pendidikan terlebih dahulu. Baik tarbiyah langsung dari lingkungan keluarga ataupun melalui sebuah lembaga pendidikan yang memadai. ${ }^{6}$

Hal tersebut membuktikna betapa pentingnya suatu pendidikan yang dilakuakan secara dzohir maupun bathin. Oleh karen itu, segala hal yang terkait di dalamnya juga menjadi sangat penting, seperti menyiapkan (alat, bahan, metode, perangkat, materi) yang berkualitas untuk diberikan kepada peserta didik. Selain itu, penyampai ilmu atau pendidik (guru/dosen) harus mampu menguasai keilmuannya sesuai dengan bidang keahliannya sehingga peserta didik dapat menerima pendidikan dengan penuh kesadaran secara ilmiah dan kenyamanan tanpa merasa dipaksa atau tertekan.

Dalam pembelajarang daring yang dilakukan untuk menekan penyebaran Covid-19 saat ini memiliki sejumlah masalah. Salah satunya adalah pendidikan tidak dapat diberikan secara tatap muka langsung antara dosen dan mahasiswa

${ }^{5}$ Heppy Atma Pratiwi, "IKLIM KOMUNIKASI DOSEN DAN MAHASISWA" 05 (2013): 9.

6 Syamsul Bachri Thalib, Psikologi pendidikan berbaris analisis empiris aplikatif (Jakarta: Kencana, 2010). 
melainkan melalui aplikasi media online seperti WhatsApp, Zoom, Google Meet dan lainnya. Hal ini tentu sangat menghambat atau bahkan menjadi masalah psikis seperti gejala stress bagi mahasiswa jika mereka tidak mengerti dan memahami tentang apa yang disampaikan oleh dosennya, segala keterbatasan tentu terjadi bagi setiap peserta didik maupun pengajar.

Mahasiswa dengan kemampuann ekonomi menengah kebawah pasti akan kesulitan dalam membeli kuota internet agar dapat mengikuti pembelajaran daring di rumah masing-masing. Jaringan internet di tiap daerah yang tidak merata, fasilitas yang minim dimiliki oleh banyak mahasiswa serta pemahaman terhadap teknologi yang kurang merata akan menjadi maslaah umum yang dimiliki oleh mahasiswa dalam mengahdapi perkuliahan daring.

Perkembangan serta penyebaran virus Covid 19 di Indonesia banyak membawa perubahan sistem, terutama sistem pendidikan. Perubahan ini terjadi dari PAUD hingga Perguruan Tinggi yang harus menaati aturan dari pemerintah agar menerapkan pembelajaran daring. Namun dalam hal ini, masih banyak kelemahan dalam proses pembelajaran ini. Mahasiswa yang juga merupakan kaum muda produktif dengan semangat untuk belajar dan beraktifitas yang tinggi mejadi terbatasi aktifitasnya. Pola komunikasi yang terjadi antara mahasiswa dengan dosen karena perbedaan umur dan zaman seringkali menjadi masalah. Mahassiswa saat ini dengan pola komunikasi yang simple, cenderung menggunakan bahassa gaul dan lebih egaliter akan dipaksa berhadapan dengan dosen yang memiliki pola komunikasi tegas, disiplin, menjunjung tinggi etika dan norma kesopanan?.

Dalam kondisi demikian, banyak mahasiswa yang miss komunikasi dengan dosennya dan berujung tidak maksimal dalam memahami pelajaran yang diberikan dan mendapat nilai minimum. Tidak sedikit mahasiswa yang mengalami gangguan psikologis seperti stress, depresi dan lainnya. Akibatnya bisa

7 Rico K Yudhaswara dan Dasrun Hidayat, "PERILAKU SELEKTIF MEMILIH INFORMASI COVID-19 DI MEDIA MASSA," t.t., 7. 
berdampak dalam pergaulan mahasiswa yang menjadi labil. Ditambah lagi dengan tugas yang cukup banyak diberikan oleh dosen untuk mahasiswa untuk menunjang pembelajaran ${ }^{8}$.

Dosen sebagai seorang pendidik dituntut untuk peka dan proaktif dalam memberikan bimbingan pembelajaran kepada mahasiswa sebagai peserta didik. Keberhasilan pembelajaran bukan diukur dari seberapa banyak materi ajar yang diberikan. Tetapi diukur dari seberapa banyak mahasiswa mampu memahami pelajaran yang diberikan. Ketidakmampuan mahasiswa dalam menerima pembelajaran karena faktor psikologis merupakan tantangan tersendiri bagi dosen untuk membimbingnya.

Tanda-tanda anak/remaja mengalami stress menurut IDAI (Ikatan Dokter Anak Indonesia ) ialah sebagai berikut ${ }^{9}$ :

1. Adanya perubahan pada perilaku yang tidak biasa (terlihat dari gestur)

2. Emosi yang tidak stabil (Mudah marah dan menangis)

3. Cenderung menarik diri dari lingkungan

4. Hilangnya nafsu makan serta sulit untuk berkonsentrasi

5. Terlihat tidak bisa tenang atau gelisah (tampak murung)

6. Mudah putus asa (kehilangan percaya diri)

7. Gangguan tidur (sulit dan sering terbangun ketika tidur, pusing bahkan hingga berdampak kepada mimpi buruk)

Dengan demikian bimbingan belajar berbasis keIslaman diharapkan menjadi solusi bagi setiap permasalahan yang dihadapi masyarakat terutama mahasiswa saat ini, untuk itu perlu adanya bimbingan belajar agar terbangun pemahaman bahwa tidak ada masalah yang tidak mempunyai jalan keluar atau solusi, terlebih bagi masyarakat atau mahasiswa yang memiliki keyakinan agama, yaitu agama Islam. Oleh karena itu dalam beberapa hal manusia harus menyadari dan merenungkan bahwa setiap kejadian yang terjadi di muka bumi adalah sudah menjadi bagian dari ketentuan Allah SWT.

8 Zaenal Abidin, "Layanan Bimbingan Belajar sebagai Upaya Peningkatan Kualitas Proses Belajar Mengajar" 11, no. 1 (t.t.): 12.

9 Binti Muawanah, "KEMATANGAN EMOSI, KONSEP DIRI DAN KENAKALAN REMAJA." 
Konsep bimbingan/konseling yang dipelopori oleh Frank Parson adalah berbentuk layanan konsultasi yang dilakukan dalam bentuk wawancara konselor (pengajar) kepada klien (peserta didik) dengan cara berkomunikasi secara langsung dan mendalam untuk memecahkan masalah, pemenuhan kebutuhan, pengubahan sikap dan tingkah laku klien(peserta didik) serta penerimaan diri. Dalam hal ini tentu ada perbedaan dengan bimbingan konseling pada umumnya, letak perbedaan tersebut terdapat pada pendekatan dan pemberian saran serta pengarahan kepada klien sesuai dengan landasan Al-Qur'an dan Al-Hadits ${ }^{10}$.

Dalam memberikan bimbingan belajar, ada beberapa hal yang harus diperhatikan oleh pengajar atau dosen dalam membentu peserta didik yang merasa tertekan hingga stress dalam menjalani pembelajaran online. Untuk keluar dari permasalahan yang dihadapi, dan dalam hal ini perlu adanya kerjasama dengan orang tua peserta didik antaralain sebagai berikut ${ }^{11}$ :

1. Membuat jadwal belajar secara Disiplin

2. Mendorong peserta didik agar mampu mengendalikan emosi terutama ketika sedang marah, kecewa atau sedih.

3. Membuat kegiatan yang mereka sukai selama berada di rumah sekaligus menyalurkan kemampuan yang mereka miliki

4. Memberikan waktu untuk bermain, berinteraksi dengan teman-temannya agar mood mereka tetap bagus saat berada di rumah.

\section{Bimbingan Belajar}

Dalam kehidupan manusia, komunikasi memiliki peranan yang sangat vital. Komunikasi merupakan sarana peting bagi pembentukan atau pengembangan pribadi dalam melakukan kontak sosial. Melalui komunikasi seseorang tumbuh dan belajar,

${ }^{10}$ Hilda Vildayanti, Irma Melyani Puspitasari, dan Rano Kurnia Sinuraya, "REVIEW: FARMAKOTERAPI GANGGUAN ANXIETAS" 16 (t.t.): 18 .

11 Ignatius Gemilau Ragil Prasetya, "BIMBINGAN BELAJAR EFEKTIF UNTUK MENINGKATKAN KEBIASAAN BELAJARPADA SISWA KELAS VII" 2, no. 1 (2013): 4. 
menemukan jati diri, beradaptasi dengan lingkungan, mencintai, mengasihi orang lain, membenci, memusuhi dan sebagainya.istilah komunikasi atau dalam bahasa inggris Communication berasal dari bahasa latin communicatio yang bersumber dari kata communis yang memiliki arti sama atau sama makna $^{12}$.

Bimbingan belajar memiliki kaitan erat dengan komunikasi. Komunikasi yang dibangun dalam bimbingan belajar memiliki pemahaman untuk menyamakan persepsi antara pengajar dengan peserta didik dengan harapan proses pembelajaran yang dilakukan dapat dicapai secara maksimal. Pesan yang disampaikan oleh pengajar kepada peserta didik dalam rangka mentransfer pengetahuan. Proses komunikasi yang baik dalam bimbingan belajar dapat mengoptimalkan hasil pembelajaran.

Seringkali ketidakpahaman dalam proses pembelajaran disebabkan oleh komunikasi yang tidak maksimal. Capaian pembelajaran yang diinginkan oleh pengajar tidak dapat dipahami oleh peserta didik. Ada beberapa kendala umum yang sering terjadi akibat komunikasi yang tidak baik dalam proses pembelajaran daring :

1. Gangguan jaringan internet yang dapat mengganggu proses interaksi

2. Bahasa yang digunakan tidak dipahami oleh salah satu pihak sehingga berujung misspersepsi atau kesalahan pemaknaan

3. Minimnya respon dalam mengikuti intruksi dalam pembelajran

\section{Masalah dalam Interaksi Belajar}

Salah satu kebijakan pemerintah dalam menghentikan penyebaran pandemi Covid -19 adalah dengan memberlakukan Work From Home pada semua lembaga termasuk lembaga pendidikan. Bagi lembaga pendidikan, WFH ini menandai proses kegiatan belajar-mengajar yang biasanya dilakukan di sekolah/kampus secara langsung untuk sementara digantikan

12 Farid Hamid dan Heri Budianto, ed., Ilmu komunikasi: sekarang dan tantangan masa depan, Ed. 1., cet. 1 (Jakarta: Kencana, 2011). 
dengan proses belajar - mengajar menggunakan sistem online dari rumah masing-masing ${ }^{13}$.

Peserta didik dan dosen tetap melaksanakan KBM seperti biasanyanamun dilakukan pada ruang yang terpisah yaitu di rumah masing - masing. Awalnya banyak pihak menilai pekerjaan ini mudah untuk dilakukan dengan cukup memiliki fasilitas seperti handphone, kuota dan jaringan yang mendukung maka kegiatan ini pasti mudah dilakukan. Namun pada kenyataannya semua masalah dan kendala mulai muncul seiring berjalannya proses kegiatan belajar mengajar ${ }^{14}$.

Sebagian mahasiswa tidak dapat mengikuti kegiatan belajar-mengajar secara online karena ketiadaan sinyal jaringan internet. Selain itu mahasiswa dengan kondisi ekonomi menengah kebawah tidak memiliki smartphone sebagai sarana belajar online. Proses kegiatan belajar-mengajar online juga memiliki kendala dalam mengontrol kehadiran mahasiswa saat KBM. Yang dapat mengikuti KBM adalah mahasiswa dengan fasilitas yang memadai sehingga pembelajaran tidak tersalurkan dengan baik. Selain itu sulit untuk mengukur partisipasi aktif proses interaksi kuliah online. Dimana dalam proses tersebut banyak sekali ditemukan mahasiswa yang melaksanakan kuliah daring sambil melakukan aktifitas lainnya dan tidak fokus dalam menjalankan perkuliahan online tersebut ${ }^{15}$.

Berdasarkan beberapa kendala tersebut tentu diperlukan solusi agar proses belajar - mengajar tetap dapat tersalurkan dengan baik sekalipun harus dilakukan di rumah. Namun solusi terbaik menekan angka penyebaran covid 19 saat ini adalah tetap berusaha sebaik mungkin dengan mengikuti tawaran belajar online serta menikuti aturan dan keputusan universitas masing-masing. Walaupun dalam segi psikologis terdapat kendala yang dihadapi ketika pembelajaran online karena adanya perubahan kebiasaan yang terjadi pada mahasiswa. Awalnya mungkin disambut dengan baik karena menjadi

13 Abidin, "Layanan Bimbingan Belajar sebagai Upaya Peningkatan Kualitas Proses Belajar Mengajar."

${ }^{14}$ Hamid dan Budianto, Ilmu komunikasi.

15 Affan Yusra, Dwi Yuwono Puji Sugiharto, dan Anwar Sutoyo, "Model Bimbingan Belajar Berbasis Prinsip-prinsip Belajar dalam Islam untuk Meningkatkan Kemanfaatan Ilmu," 2017, 7. 
sesuatu yang baru dan berbeda, namun setelah dijalankan justru membuat para mahasiswa menjadi jenuh dengan rutinitas yang harus dilakukan setiap harinya tersebut ${ }^{16}$.

Distraction menjadi salah satu alasan fokus pembelajaran melalui daring sulit dibangun. Kunci membangun fokus bergantung pada dorongan eksternal yang secara garis besar ada dua prinsip, yaitu prinsip kesenangan dan prinsip aturan. Prinsip kesenangan didasari pada dorongan melakukan sesuatu yang disukai dan tertarik untuk dilakukan. Hal ini tentu saja dapat membangun fokus karena menyukai subjeknya tersebut. Yang kedua adalah prinsip aturan yang didasari pada dorongan melakukan sesuiatu karena tuntutan aturan yang memiliki akibat. Prinsip tersebut juga dapat mendorong kemauan seseorang untuk melakukan sesuatu dan mendorong fokus. Adapun mengenai solusi untuk mengatasi gangguan tersebut yaitu $^{17}$ :

a. Mengetahui prinsip apa yang mendominasi seseorang. Prinsip kesenangan atau prinsip aturan

b. Jika salah satu prinsip lebih dominan, maka cobalah untuk menyeimbangkannya

c. Harus dapat membangun fokus terutama dalam kegiatan belajar dari rumah secara daring

Proses mendapatkan pengetahuan dan ketrampilan individu serta perubahan sikap dan prilaku dapat terjadi karena hasil penemuan pemahaman yang datang dapat melalui apa saja termasuk dalam bimbingan belajar. Selain itu juga dapat diperoleh melalui interaksi antara pengalaman baru dengan pengalaman yang pernah dialami sebelumnya. Pengalaman yang dialami tersebut dapat terjadi baik secara langsung maupun tidak langsung melalui perantara media ${ }^{18}$.

Proses belajar untuk memperoleh pengalaman baru tersebut menurut bruner dapat terjadi kedalam 3 tingkatan yaitu,

16 Thalib, Psikologi pendidikan berbaris analisis empiris aplikatif.

17 Okta Diferiansyah, Tendry Septa, dan Rika Lisiswanti, “Gangguan Cemas Menyeluruh," t.t., 6.

18 Syamsu Yusuf, Psikologi perkembangan anak dan remaja (Bandung, Indonesia: PT Remaja Rosdakaryam, 2011). 
enactive (pengalaman langsung), iconic (pengalaman piktorial/gambar), dan symbolic (pengalaman abstrak). enactive adalah dengan terlibat langsung secara aplikatif atau mengerjakan sesuatu. Misalnya dengan membangun team building, yang dapat dilakukan secara langsung dengan permainan-permainan kekompakan seperti outbond. Tingkatan kedua yang melalui label iconic misalnya pola sikap ketika berbicara di depan umum dapat dipelajari melalui gambar, lukisan atau film yang menyajikan prilaku tersebut. Meskipun individu tersebut belum pernah berbicara di depan umum secara formal, melalui media tersebut mereka dapat mempelajari dan memmahaminya dari gambar, lukisan, foto, atau film. Selanjutnya pada tingkatan Symbolic, indvidu membaca atau mendengar kata "pura-pura bahagia" pada gambaran mental yang dipikirkan atau mencocokannya dengan pengalaman yang serupa. Ketiga tingkat pengalaman ini saling berinteraksi dalam upaya memperoleh pengalaman baru.

Tingkatan ini dimaksukan bahwa jika penyerapan lebih banyak indera yang digunakan, akan lebih baik hasilnya daripada mengandalkan satu indera saja. Belajar menggunakan indera melihat dan dengar berdasarkan konsep di atas akan memberikan keuntungan bagi individu untuk belajar lebih banyak daripada jika materi pelajaran hanya disajikan dengan stimulus melihat atau hanya dengan stimulus dengar saja, para ahli memiliki melihatan yang searah mengenai hal tersebut. Perbandingan perolehan hasil belajar melalui indera melihat dan indera pendengar sangat berbeda ${ }^{19}$.

Menururt Achsin kurang lebih sekitar 80\% hasil belajar diperoleh melalui indera melihat, dan hanya sekitar $10 \%$ melalui indera dengar dan $10 \%$ lagi melalui indera lainnya ${ }^{20}$. Sementara Dale memperkirakan bahwa perolehan hasil belajar melalui indera melihat berkisar $65 \%$, melalui indera dengar $23 \%$, dan melalui indera lainnya sekitar $12 \%$. Stimulus visual membuahkan hasil belajar dan pemahaman yang lebih baik untuk tugas-tugas seperti mengenali, mengingat kembali dan menghubungkan fakta dan konsep. Dilain pihak, stimulus verbal memberikan

19 Thalib, Psikologi pendidikan berbaris analisis empiris aplikatif.

20 Prasetya, "BIMBINGAN BELAJAR EFEKTIF UNTUK MENINGKATKAN KEBIASAAN BELAJARPADA SISWA KELAS VII." 
hasil belajar yang lebih baik jika prosesnya melibatkan ingatan yang berurutan (sekuensiali). Ini adalah bukti dukungan atas konsep dual coding hypothesis (hipotesis koding ganda) dari plavio $^{21}$.

\section{Bimbingan Belajar dalam Islam}

Belajar merupakan suatu aktifits yang dilakukan oleh manusia dalam rangka mengkualitaskan dirinya untuk mampu menjadi makhluk yang lebih baik dari sebelumnya. Al Ghazali (pemikir Islam) memberikan pemahaman pendekatan belajar dalam mencari ilmu dapat dilakukan dengan melakukan dua pendekatan, yakni Ta'lim Insani dan Ta'lim Rabbani. Ta'lim Insani adalah belajar dengan bimbingan orang lain. Pendekatan ini merupakan hal yang lazim dilakukan oleh manusia dan biasanya menggunakan alat indrawi yang diakui oleh orang berakal, menurut Al-Ghazali, dalam proses belajar mengajar selalu terjadi eksplorasi pengetahuan sehingga menghasilkan perubahanperubahan perilaku. Dalam proses ini peserta didik akan mengalami proses mengetahui yaitu proses abstraksi22.

Sedangkan menurut Al Zarnuji belajar merupakan ibadah dan mengantarkan seseorang untuk memperoleh kebahagiaan duniawi dan ukhrawi. Karenanya belajar harus diawali dengan niat untuk mencari ridha Allah, kebahagiaan akhirat, mengembangkan dan melesarikan Islam, mensyukuri nikmat akal dan menghilangkan kebodohan. Seseorang yang sedang belajar harus memiliki 6 syarat agar mudah mendapatkan ilmu. Jika 6 syarat itu tidak terpenuhi maka individu akan mengalami kesulitan belajar. Enam perkara itu adalah cerdas, semangat, sabar, memiliki biaya, guru dan dalam waktu yang lama/kontinuitas ${ }^{23}$.

Dalam Islam, belajar memiliki tujuan belajar yang berjangka panjang dan jangka pendek. Adapun jangka panjang yaitu agar memaksimalkan potensi akal (fitrah 'aql) dan juga memaksimalkan potensi jiwa (fitrah qalb) yang telah diberikan

21 "Komunikasi Verbal dan Non Verbal.pdf," t.t.

22 Abidin, "Layanan Bimbingan Belajar sebagai Upaya Peningkatan Kualitas Proses Belajar Mengajar."

23 Acep Aripudin, Dakwah antarbudaya, Cet. 1 (Bandung: Remaja Rosdakarya, 2012). 
oleh Allah SWT agar dapat berkembang dan berfungsi dengan baik, sehingga mereka dapat terhindar dari kesulitan-kesulitan belajar dan pada akhirnya mereka menjadi pribadi-pribadi yang cerdas, beriman dan berakhlaul karimah. Atau dapat disimpulkan bahwa tujuan akhir dari bimbingan belajar menurut Islam adalah mengembangkan dan mempertajam akal pikiran dan melembutkan hati peserta didik yang dibimbing sehingga dapat menjadi pribadi yang cerdas, beriman dan berakhlaul karimah yang pada akhirnya diharapkan mereka bisa hidup bahagia di dunia dan akhirat ${ }^{24}$.

Selanjutnya, tujuan jangka pendek yang ingin dicapai agar kecerdasannya dapat menuntutn mereka dalam memahami ayat-ayat Allah qauliyah (Al-Qur'an dan Hadits) dan kauniyah (ayat-ayat Allah yang terbentang di jagat raya) secara mudah yang pada akhirnya akan melahirkan amal shaleh yang dilandasi dengan keyakinan yang benar berdasarkan nilai-nilai AlQur'an ${ }^{25}$. Keyakinan tersebut dpat menjadikan peserta didik :

a) Memiliki sikap dan kebiasaan belajar yang baik dengan dilandasi nilai-nilai Al-qur' an seperti memulai belajar dengan berdoa (QS. 7:55), memuliakan ilmu (QS. 5:6), memuliakan guru (QS. 58:11) dan memiliki sikap tawadhu (QS.25:63)

b) Memiliki motivasi yang tinggi untuk belajar spanjang hayat, bukan untuk ditujukan mencari keuntungan duniawi, tapi semata-mata untuk menyempurnakan kualitas diri sebagai hamba Allah yang beriman, berilmu dan beramal shalil

c) Memiliki orientasi belajar sepanjang dan sejagat hayat

d) Belajar bukan sekedar untuk menarik perhatian manusia, menyayangi orang 'alim dan berdekat dengan orang bodoh

e) Setiap individu harus mengamalkan ilmu yang dipelajarinya (QS. 3:187). Orang yang mengamalkan ilmu mendapat pahal, sedangkan orang yang tidak mau mengamalkan ilmunya adalah sesat dan menyesatkan

24 Yusra, Sugiharto, dan Sutoyo, "Model Bimbingan Belajar Berbasis Prinsip-prinsip Belajar dalam Islam untuk Meningkatkan Kemanfaatan Ilmu."

25 Thalib, Psikologi pendidikan berbaris analisis empiris aplikatif. 
f) Memiliki ketrampilan atau tekhnik belajar yang efektif, seperti ketrampilan menghafal, mampu berdiskusi, bermusyawarah, dan berdebat secara positif dan bertanggung jawab. Landasan utama dari semua hal tersebut adalah keikhlasan untuk saling menyempurnakan diantara peserta didik dengan peserta didik lainnya. Dari sini diharapkan akan terbentuk peserta didik yang cerdas baik intelektualnya, psikososialnya, emosionalnya dan spiritualnya.

g) Memiliki ketrampilan untuk menetapkan tujuan dan perencanaan pendidikan baik jangka pendek yang diwujudkan dalam aktifitas belajarnya dan tujuan jangka panjang untuk memperoleh kemuliaan di sisi Allah SWT (QS.58:11)

h) Memiliki pemahaman yang benar akan makna belajar, bahwa bellajar merupakan kewajiban (QS 9 :122) dan aktifitas yang bernilai ibadah.

i) Memiliki tujuan belajar yang benar sesuai ajaran Islam yaitu mengharapkan ridha Allah SWT (QS. 58:11)

j) Memiliki kesiapan mental dan kemampuan untuk menghadapi ujian, tidak hanya dalam bentuk ujian terhadap mata kuliah tapi juga ujian dalam menghadapi kehidupan yang lebih kompleks. Dengan cara belajar secara sungguhsungguh (QS.26:69), tidak mudah putus asa (QS.12:87) dan setelah itu tawakal (menyerahkan hasil) hanya kepada Allah SWT (QS. 65:3, 3:122)

\section{Kesimpulan}

Dunia yang sedang dilanda pandemi virus Covid 19 membuat banyak negara mengeluarkan kebijakan untuk menekan penyebaran wabah tersebut. Kebijakan pmerintah Indonesia dalam menekan angka penyebaran covid 19 sekaligus menjamin kegiatan belajar-mengajar tetap berjalan adalah dengan melakukan belajar dari rumah melalui pembelajar daring/online.

Ditemukan berbagai permasalahan yang cukup penting yaitu komunikasi yang tidak efektif dan kejenuhan belajar akibat pembelajaran daring. Selain itu juga terdapat beberapa kendala terkait fasilitas yang kurang baik berupa jaringan yang tidak 
merata di berbagai wilayah serta kemampuan mengakses teknologi dan membeli kuota internet dan smartphone yang dapat menunjang pembelajaran online.

Pengajar/dosen memiliki kewajiban untuk mengatasi berbagai maslah dan kendala tersebut. Salah satunya adalah dengan memberikan bimbingan belajar yang efektif dan efisien dengan memanfaatkan tekhnologi secara maksimal. Bimbingan belajar menurut ajaran agama Islam ada beberapa prinsip dasar, yaitu :

1) Bimbingan belajar qurani ditujukan untuk terbentuknya peserta didik yang cerdas, bertakwa dan berakhlak mulia. Untuk sampai pada tujuan ini bimbingan belajar tidak hanya ditujukan untuk mengembangkan dan memaksimalkan fungsi otak. Tapi perlu diimbangi dengan mengembangkan dan memaksimalkan fungsi hati/kalbu. Ini mengandung pengertian adanya keseimbangan antara aktifitas zikir dan fakir (QS. 3 : 190-191)

2) Bimbingan belajar tidak hanya diberikan bagi peserta didik yang mengalami kesulitan dan masalah dalam belajarnya, tapi ditujukan bagi semua peserta didik

3) Aktifitas belajar dan membimbing merupakan aktifitas ibadah kepada Allah SWT. Untuk itu baik peserta didik maupun pembimbing perlu meluruskan niat sebelum melakukan aktifitasnya untuk mengharap ridha Allah SWT.

Selain prinsip dasar tersebtu, terdapat juga prinsip yang dipegang teguh oleh seorang pengajar sebagai subjek yang melakukan bimbingan agar dapat memaksimalkan bimbingan kepada peserta didik. Prinsip yang berhubungan dengan pembimbing/dosen dalam ajaran agama Islam antara lain :

a) Membimbing adalah aktifitas ibadah, karenanya pelakunya diberikan pahala/kebaikan (QS. 4:146)

b) Karena merupakan aktifitas ibadah, maka harus dilakukan dengan cara-cara yang benar. Karena aktifitas bimbingannya akan dipertanggungjawabkan baik dihadapan manusia dan terlebih dahulu dihadapan Allah (QS. 15:92-93)

c) Dosen/pembimbing memiliki ketrampilan dan menguasai tekhnik belajar yang memadai dalam membimbing peserta 
didik berdasarkan prinsip-prinsip belajar qurani. Untuk itu dosen/pembimbing adalah orang yang berilmu/berwawasan luas (QS. 2:44)

d) Dosen/Pembimbing mampu menjadi teladan bagi peserta didik yang tercermin dalam perbuatannya yang sesuai dengan nilai-nilai Al-Qur'an dan berakhlak mulia sebagaimana dicontohkan oleh Rasulullah SAW (QS. 33:21)

\section{DAFTAR PUSTAKA}

Abidin, Zaenal. "Layanan Bimbingan Belajar sebagai Upaya Peningkatan Kualitas Proses Belajar Mengajar" 11, no. 1 (t.t.): 12.

Aripudin, Acep. Dakwah antarbudaya. Cet. 1. Bandung: Remaja Rosdakarya, 2012.

Bimbingan Belajar "Antara Metode Belajar Di Kelas Sampai Online ". Jakarta: Tempo Publishing, 2019.

Binti Muawanah, Lis. "KEMATANGAN EMOSI, KONSEP DIRI DAN KENAKALAN REMAJA." Persona:Jurnal Psikologi Indonesia 1, no. 1 (1 Juni 2012). https://doi.org/10.30996/persona.v1i1.9.

Diferiansyah, Okta, Tendry Septa, dan Rika Lisiswanti. "Gangguan Cemas Menyeluruh," t.t., 6.

Hamid, Farid, dan Heri Budianto, ed. Ilmu komunikasi: sekarang dan tantangan masa depan. Ed. 1., cet. 1. Jakarta: Kencana, 2011.

"Komunikasi Verbal dan Non Verbal.pdf," t.t.

Prasetya, Ignatius Gemilau Ragil. "BIMBINGAN BELAJAR EFEKTIF UNTUK MENINGKATKAN KEBIASAAN BELAJARPADA SISWA KELAS VII" 2, no. 1 (2013): 4.

Pratiwi, Heppy Atma. "IKLIM KOMUNIKASI DOSEN DAN MAHASISWA" 05 (2013): 9.

"Qur'an Kemenag." Diakses 9 September 2019. https://quran.kemenag.go.id/.

Thalib, Syamsul Bachri. Psikologi pendidikan berbaris analisis empiris aplikatif. Jakarta: Kencana, 2010.

Vildayanti, Hilda, Irma Melyani Puspitasari, dan Rano Kurnia Sinuraya. "REVIEW: FARMAKOTERAPI GANGGUAN ANXIETAS" 16 (t.t.): 18. 
Yudhaswara, Rico K, dan Dasrun Hidayat. "PERILAKU SELEKTIF MEMILIH INFORMASI COVID-19 DI MEDIA MASSA," t.t., 7.

Yusra, Affan, Dwi Yuwono Puji Sugiharto, dan Anwar Sutoyo. "Model Bimbingan Belajar Berbasis Prinsip-prinsip Belajar dalam Islam untuk Meningkatkan Kemanfaatan Ilmu," 2017, 7.

Yusuf, Raka, Harni Kusniyati, dan Yurike Nuramelia. "APLIKASI DIAGNOSIS GANGGUAN KECEMASAN MENGGUNAKAN METODE FORWARD CHAINING BERBASIS WEB DENGAN PHP DAN." Jurnal Sistem Informasi, 2016, 13.

Yusuf, Syamsu. Psikologi perkembangan anak dan remaja. Bandung, Indonesia: PT Remaja Rosdakaryam, 2011. 